\title{
Induksi Pembungaan Rambutan dengan Aplikasi Paklobutrazol
}

\author{
Flowering Induction in Rambutan by Paclobutrazol Application
}

\author{
Theresia Prawitasari ${ }^{1 *}$, Dorly ${ }^{1}$, Sri Wahyuni ${ }^{1}$ \\ ${ }^{1}$ Departemen Biologi,FMIPA, Institut Pertanian Bogor, Bogor 16141 \\ Tel./Fax. +62 -0251-345011E-mail: th_wita@yahoo.com *Penulis untuk korespondensi
}

\begin{abstract}
Rambutan fruit have a great potential to be developed as an exported commodity. The constraint is the existence of biannual bearing characteristic of the plant, which is an alternation of fruit yield between on year and off year. This condition resulted in a problem in product availability continuity. The aim of this research was to induce rambutan plant flowering in the off year with the application of paclobutrazol. There were three doses of paclobutrazol treatment including $0 \mathrm{~g} /$ tree, $1.5 \mathrm{~g} /$ tree, and $3 \mathrm{~g} /$ tree. Bud dormancy as an implication of paclobutrazol application were broken by the application of $\mathrm{KNO}_{3}$ at $20 \mathrm{~g} / \mathrm{l}$ concentration. The experiment was arranged in completely randomized factorial design $3 \times 2$ in triplicate. The result showed that paclobutrazol treatment was able to induce rambutan flowering in the off year. Paclobutrazol treatment significantly increased the number of generative buds. Based on the generative bud percentage, the higher doses of paclobutrazol application the stronger stimulus of flowering. Paclobutrazol treatment also reduced the inflorescences length and increased the chlorophyll content of the flowering support leaves. It seems that application at dose $3 \mathrm{~g} /$ tree caused bud dormancy but dose $1.5 \mathrm{~g} /$ tree did not. Bud dormancy as a result of paclobutrazol application could be broken by the $\mathrm{KNO}_{3}$ application. The optimum dose to induced rambutan flowering was $1.5 \mathrm{~g} /$ tree because this dose seems did not caused bud dormancy and gave a higher number of generative buds compared to $3 \mathrm{~g} /$ tree dose.
\end{abstract}

Key words: paclobutrazol, rambutan, flowering, chlorophyll content

Diterima: 24 Februari 2004, disetujui: 02 Maret 2004

\section{Pendahuluan}

Buah rambutan memiliki bentuk dan warna yang menarik dengan rasa yang manis, segar, serta mengandung gizi yang baik. Karena itu buah rambutan berpotensi besar untuk dikembangkan sebagai komoditas ekspor, baik sebagai buah segar maupun sebagai buah olahan. Kendala yang dihadapi adalah adanya sifat biannual bearing pada tanaman rambutan. Biannual bearing yaitu perselang-selingan pembuahan antara off year dan on year. Tanaman berbunga dan berbuah banyak pada suatu tahun (on year) dan berbuah sedikit pada tahun berikutnya (off year) (Tromp, 2000). Sifat biannual bearing ini menimbulkan kendala kontinuitas ketersediaan produk.

Selain sifat biannual bearing, tanaman rambutan memiliki sifat berbunga dan berbuah serempak dengan musim berbuah berlangsung singkat. Musim berbunga rambutan terjadi sekitar bulan Juli-Oktober dengan musim panen sekitar bulan November-Februari (Irdiastuti 2002). Masa panen yang berlangsung singkat dan masa simpan yang pendek menyebabkan suplai jauh lebih besar dibandingkan permintaan pasar pada masa panen sehingga harga buah merosot (Subhadrabandhu and Tongumpai, 1990). Di lain pihak terjadi kekosongan produksi buah di luar musim sehingga kontinuitas produksi buah untuk konsumsi 
dalam negeri dan ekspor terganggu. Untuk mengatasi hal tersebut perlu dilakukan manipulasi budidaya dengan mengatur waktu pembungaan dan pembuahan agar terjadi kesinambungan produksi sepanjang tahun.

Salah satu teknik untuk menstimulasi pembungaan rambutan di luar musim adalah dengan aplikasi paklobutrazol. Paklobutrazol merupakan senyawa penghambat biosintesis giberellin yang dapat menghambat pertumbuhan vegetatif dan menstimulasi pembungaan. Giberellin diketahui merupakan penghambat pembungaan pada Angiospermae berkayu (Levy and Dean, 1998). Paklobutrazol menghambat tahap awal biosintesis giberellin (GA) yaitu oksidasi ent kaurene menjadi asam ent kaurenoat (Mehouachi et al., 1996)

Aplikasi paklobutrazol menyebabkan dormansi tunas sehingga diikuti oleh aplikasi $\mathrm{KNO}_{3}$ sebagai senyawa pemecah dormansi tunas. Dosis $\mathrm{KNO}_{3}$ yang diaplikasikan merujuk pada penelitian Rasiyanto (2001) yaitu 20 g/l. Menurut Berova and Zlatev (2000), perlakuan paklobutrazol dapat menginduksi perubahan kandungan pigmen fotosintetik. Karena itu pada penelitian ini akan diuji pula pengaruh paklobutrazol terhadap kadar klorofil daun. Lang dalam Ryugo (1988) membagi proses pembungaan menjadi empat tahap yaitu 1 . induksi, evokasi, dan inisiasi, 2. diferensiasi bunga, 3. pendewasaan organ-organ bunga, dan 4. anthesis. Pengamatan tahapan pembungaan pada penelitian ini didasarkan pada pembagian tersebut yaitu induksi, inisiasi, dan diferensiasi.

Penelitian ini bertujuan mengetahui dosis optimum paklobutrazol untuk menginduksi pembungaan rambutan di luar musim, mempelajari pengaruh aplikasi paklobutrazol terhadap perubahan fisiologi selama pembungaan, dan mempelajari pengaruh aplikasi $\mathrm{KNO}_{3}$ setelah aplikasi paklobutrazol.

\section{Metode Penelitian}

\section{Waktu dan Tempat Penelitian}

Penelitian dilaksanakan bulan Januari hingga Juli 2003, bertempat di kebun koleksi PT Inti Daya Agro Lestari (Inagro) Parung, Laboratorium Fisiologi Tumbuhan, serta

Biota Vol. X (2), Juni 2005
Laboratorium Anatomi dan Morfologi Tumbuhan.

Bahan dan Alat. Bahan tanaman yang digunakan adalah pohon rambutan varietas Binjai berumur enam tahun koleksi PT Inagro. Bahan kimia yang digunakan yaitu Cultar 250 EC yang mengandung $250 \mathrm{~g}$ paklobutrazol/l, $\mathrm{KNO}_{3}$, dan bahan-bahan kimia untuk analisis kandungan klorofil. Alat yang digunakan antara lain jangka sorong, sprayer, sentrifuse berpendingin, dan spektrofotometer.

\section{Metode Aplikasi Paklobutrazol dan KNO3}

Paklobutrazol diaplikasikan dengan cara penyiraman (soil drench) pada tanggal 27 Januari 2003. Aplikasi $\mathrm{KNO}_{3}$ dilakukan 32 hari setelah aplikasi paklobutrazol, yaitu tanggal 28 Februari 2003, dengan cara penyemprotan (foliar spray) pada daun dan tunas yang terinduksi untuk berbunga.

\section{Pengamatan Pembungaan}

Pengamatan pembungaan dilakukan pada 2-14 minggu setelah aplikasi paklobutrazol (2 14 MSAP). Peubah yang diamati meliputi waktu induksi, waktu inisiasi, waktu diferensiasi, jumlah tunas generatif, pertambahan panjang tunas generatif dan malai bunga, persentase jumlah tunas terinisiasi, terdiferensiasi dan gugur. Selama pengamatan pembungaan dilakukan pula pengamatan morfologi daun pada fase induksi, tonjolan primordia malai bunga pada fase inisiasi, dan perkembangan malai pada fase diferensiasi.

\section{Analisis Kandungan Klorofil Daun}

Analisis kandungan klorofil daun dilakukan dengan menggunakan metode Aronoff and MacKinney yang dimodifikasi (Arnon 1949). Sebanyak 0,43 g daun digerus dengan $10 \mathrm{ml}$ buffer fosfat $1 / 15 \mathrm{M} \mathrm{pH}$ 6,5. Hasil gerusan disentrifuse dengan kecepatan $3000 \mathrm{rpm}$ pada suhu $4^{\circ} \mathrm{C}$ selama 1 menit. Supernatan hasil sentrifuse tahap pertama kembali disentrifuse dengan kecepatan 12000 rpm pada suhu $4^{\circ} \mathrm{C}$ selama 20 menit. Pelet hasil sentrifuse tahap kedua diresuspensi dalam $5 \mathrm{ml}$ buffer fosfat $1 / 15 \mathrm{M} \mathrm{pH}$ 6,5. Sebanyak 0,5 
$\mathrm{ml}$ suspensi klorofil tersebut dilarutkan dalam $20 \mathrm{ml}$ aseton $80 \%$. Absorbansi larutan klorofil diukur menggunakan spektrofotometer pada panjang gelombang $(\lambda) 645 \mathrm{~nm}$ dan $663 \mathrm{~nm}$. Kandungan klorofil total (K) dalam mg/l dihitung dengan menggunakan persamaan $\mathrm{K}=$ $20,2 \mathrm{D}_{645}+8,02 \mathrm{D}_{663}$. Penelitian ini didukung oleh data sekunder berupa data curah hujan harian yang diperoleh dari Stasiun Klimatologi Darmaga Bogor.

\section{Rancangan Percobaan}

Penelitian disusun menggunakan Rancangan Acak Lengkap faktorial. Faktor pertama adalah dosis aplikasi paklobutrazol yang terdiri dari tiga taraf dosis yaitu: $\mathrm{P} 0=0,0 \mathrm{~g}$ bahan aktif/pohon; $\mathrm{P} 1=1,5 \mathrm{~g}$ bahan aktif/pohon; dan $\mathrm{P} 2=3,0 \mathrm{~g}$ bahan aktif/pohon. Faktor kedua adalah aplikasi $\mathrm{KNO}_{3}$ yaitu: $\mathrm{K} 0=$ tanpa pemberian $\mathrm{KNO}_{3}$ dan $\mathrm{K} 1=$ dengan pemberian $\mathrm{KNO}_{3}$. Setiap kombinasi perlakuan diulang sebanyak tiga kali. Data diolah menggunakan program SAS (Statistical Analysis System) versi 6.12.

\section{Hasil dan Pembahasan}

\section{Waktu Induksi}

Induksi pembungaan adalah tahap dimana tunas vegetatif terstimulasi secara biokimia dan berubah menjadi tunas reproduktif. Pada tahap ini belum terjadi perubahan morfologi tunas yang dapat teramati dari luar (Ryugo, 1988). Transisi dari fase vegetatif menuju fase reproduktif seringkali ditandai dengan perubahan morfologi struktur vegetatif seperti perubahan morfologi daun (Levy and Dean, 1998). Pada tanaman rambutan, tunas yang terinduksi untuk berbunga dicirikan dengan perubahan morfologi daun dewasa pendukung pembungaan. Helai daun pendukung induksi pembungaan lebih kaku, berwarna lebih gelap dan permukaan atas helai daun lebih berkilap (Gambar 1).

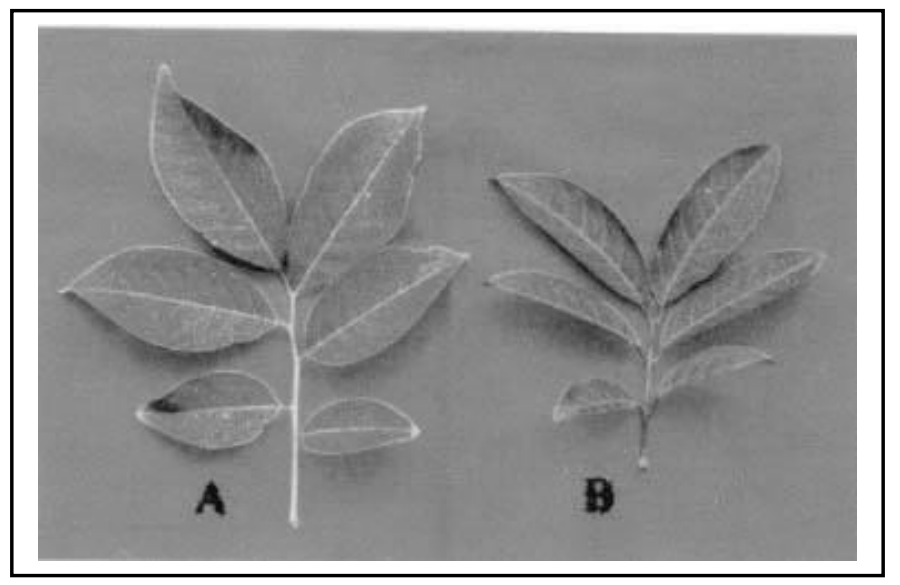

Gambar 1. Perbandingan daun vegetatif (A) dan daun pendukung induksi pembungaan (B).

Berdasarkan hasil (Tabel 2) perlakuan paklobutrazol dapat menginduksi pembungaan tanaman rambutan di luar musim. Tanaman yang diperlakukan dengan paklobutrazol dosis $1,5 \mathrm{~g} /$ pohon $(\mathrm{P} 1)$ rata-rata pertama terinduksi untuk berbunga 23 hari setelah aplikasi paklobutrazol (HSAP). Dosis aplikasi paklobutrazol yang tinggi yaitu $3 \mathrm{~g} /$ pohon (P2) mempercepat terinduksinya tunas untuk berbunga, dengan rataan waktu induksi 21 HSAP (Hari Setelah Apilikasi Paklobutrazol).
Empat dari enam tanaman tanpa perlakuan paklobutrazol (P0) dapat terinduksi untuk berbunga meskipun tidak diaplikasikan paklobutrazol, dengan rataan waktu induksi 30 HSAP.

Menurut Thunyarpar (1997) tanaman dari famili Sapindaceae dapat terinduksi secara alami untuk berbunga bila curah hujan kurang dari $40 \mathrm{~mm} / \mathrm{minggu}$. Dari hasil (Tabel 2) terlihat bahwa seluruh tanaman yang diperlakukan dengan paklobutrazol dapat 
terinduksi untuk berbunga walaupun jumlah curah hujan per minggu jauh di atas $40 \mathrm{~mm}$ yaitu rata-rata $128 \mathrm{~mm} / \mathrm{minggu}$ untuk perlakuan P1 dan $135 \mathrm{~mm} / \mathrm{minggu}$ untuk perlakuan P2. Empat dari enam tanaman tanpa perlakuan paklobutrazol ternyata juga mampu untuk terinduksi walaupun jumlah curah hujan per minggu lebih dari $40 \mathrm{~mm}$. Namun bila dilihat dari curah hujan harian terlihat bahwa semua tanaman tanpa perlakuan paklobutrazol terinduksi bila sehari sebelumnya curah hujan sangat rendah, yaitu rata-rata $3 \mathrm{~mm} / \mathrm{hari}$. Sedangkan tanaman yang diperlakukan dengan paklobutrazol tetap dapat terinduksi walaupun sehari sebelumnya curah hujan cukup tinggi, yaitu rata-rata $30,67 \mathrm{~mm} /$ hari untuk perlakuan $\mathrm{P} 1$ dan $36 \mathrm{~mm} /$ hari untuk perlakuan P2.

Paklobutrazol sebagai inhibitor biosintesis GA (Gibberellic Acid) dapat menurunkan kandungan GA endogen. Efek ini sendiri dapat menstimulasi pembungaan tanaman berkayu karena GA merupakan penghambat pembungaan Angiospermae berkayu, termasuk rambutan (Levy and Dean, 1998). GA menginduksi pertumbuhan vegetatif termasuk pemanjangan batang di bawah apeks (meristem pucuk). Proses ini berkorelasi dengan penurunan kandungan sukrosa apeks karena menyebabkan teralihkannya asimilat menjauh dari apeks dan menuju jaringan batang yang sedang memanjang. Dengan demikian kandungan sukrosa apeks tetap rendah, padahal sukrosa merupakan stimulus pembungaan (King and Ben-Tal, 2001).

Hasil penelitian ini sesuai dengan hasil penelitian-penelitian sebelumnya diantaranya penelitian Kurian and Iyer (1993). Menurut Kurian and Iyer (1993) paklobutrazol dapat memacu pembungaan mangga lebih awal sekaligus memperbanyak jumlah bunga.

Tabel 2 Pengaruh perlakuan paklobutrazol terhadap waktu pertama induksi dihubungkan dengan curah hujan serta pengaruh perlakuan paklobutrazol dan $\mathrm{KNO}_{3}$ terhadap waktu pertama inisiasi dan diferensiasi tunas bunga

\begin{tabular}{|c|c|c|c|c|c|c|c|c|c|c|c|c|}
\hline \multicolumn{2}{|c|}{ Perlakuan } & \multirow{2}{*}{ Ul } & \multicolumn{2}{|c|}{ Waktu Induksi } & \multicolumn{2}{|c|}{$\begin{array}{c}\text { Curah Hujan } \\
\text { (mm) }\end{array}$} & \multicolumn{3}{|c|}{ Waktu Inisiasi } & \multicolumn{3}{|c|}{ Waktu Diferensiasi } \\
\hline $\begin{array}{l}\text { Paklo- } \\
\text { butrazol }\end{array}$ & $\mathrm{KNO}_{3}$ & & $\mathrm{Tgl}$ & HSAP & $\begin{array}{c}\text { Per } \\
\text { Minggu }\end{array}$ & HI-1 & Tgl & HSAP & HSAK & Tgl & HSAP & HSAK \\
\hline \multirow[t]{6}{*}{ P0 } & & $\overline{11}$ & $\overline{\text { Tidak Te }}$ & $\overline{\text { rinduksi }}$ & & & & & & & & \\
\hline & K0 & 2 & Tidak Te & & & & & & & & & \\
\hline & & 3 & $28 \mathrm{Feb}$ & 32 & 90 & 4 & \multicolumn{3}{|c|}{ Tidak Terinisiasi } & & & \\
\hline & K1 & 1 & $20 \mathrm{Feb}$ & 24 & 133 & 0 & $28 \mathrm{Feb}$ & 32 & & \multicolumn{3}{|c|}{ Tidak Terdiferensiasi } \\
\hline & & 2 & $28 \mathrm{Feb}$ & 32 & 90 & 4 & $7 \mathrm{Mar}$ & 39 & 7 & $11 \mathrm{Mar}$ & 43 & 11 \\
\hline & & 3 & $28 \mathrm{Feb}$ & 32 & 90 & 4 & \multicolumn{3}{|c|}{ Tidak Terinisiasi } & & & \\
\hline \multirow[t]{6}{*}{$\mathrm{P} 1$} & K0 & 1 & $18 \mathrm{Feb}$ & 22 & 133 & 28 & $20 \mathrm{Feb}$ & 24 & - & $25 \mathrm{Feb}$ & 29 & \\
\hline & & 2 & $18 \mathrm{Feb}$ & 22 & 133 & 28 & $20 \mathrm{Feb}$ & 24 & - & $25 \mathrm{Feb}$ & 29 & \\
\hline & & 3 & $28 \mathrm{Feb}$ & 32 & 90 & 4 & \multicolumn{3}{|c|}{ Tidak Terinisiasi } & & & \\
\hline & $\mathrm{K} 1$ & 1 & $14 \mathrm{Feb}$ & 18 & 144 & 68 & $18 \mathrm{Feb}$ & $22 *$ & & $20 \mathrm{Feb}$ & 24 & \\
\hline & & 2 & $18 \mathrm{Feb}$ & 22 & 133 & 28 & $25 \mathrm{Feb}$ & $29^{*}$ & & $7 \mathrm{Mar}$ & 39 & 7 \\
\hline & & 3 & $18 \mathrm{Feb}$ & 22 & 133 & 28 & $25 \mathrm{Feb}$ & $29^{*}$ & & 3 Mar & 35 & 3 \\
\hline \multirow[t]{6}{*}{$\mathrm{P} 2$} & K0 & 1 & $14 \mathrm{Feb}$ & 18 & 144 & 68 & $18 \mathrm{Feb}$ & 22 & - & $20 \mathrm{Feb}$ & 24 & \\
\hline & & 2 & $18 \mathrm{Feb}$ & 22 & 133 & 28 & $18 \mathrm{Mar}$ & 50 & - & $28 \mathrm{Mar}$ & 60 & \\
\hline & & 3 & \multicolumn{4}{|c|}{ Diserang hama ulat } & & & & & & \\
\hline & $\mathrm{K} 1$ & 1 & $18 \mathrm{Feb}$ & 22 & 133 & 28 & \multicolumn{3}{|c|}{ Terpangkas } & & & \\
\hline & & 2 & $18 \mathrm{Feb}$ & 22 & 133 & 28 & 7 Mar & 39 & 7 & 14 Mar & 46 & 14 \\
\hline & & 3 & $18 \mathrm{Feb}$ & 22 & 133 & 28 & 7 Mar & 39 & 7 & $11 \mathrm{Mar}$ & 43 & 11 \\
\hline
\end{tabular}

Keterangan : HI-1 = Hari Induksi - 1, yaitu nilai curah hujan $(\mathrm{mm})$ sehari sebelum induksi terjadi.

HSAP = Hari Setelah Aplikasi Paklobutrazol.

$\mathrm{HSAK}=$ Hari Setelah Aplikasi $\mathrm{KNO}_{3}$.

* = tanaman perlakuan P1 yang telah terinisiasi sebelum aplikasi $\mathrm{KNO}_{3}$. 


\section{Waktu Inisiasi dan Diferensiasi}

Waktu inisiasi adalah saat dimana tunas yang terinduksi telah menampakkan perubahan morfologi berupa tonjolan primordia malai bunga. Aplikasi paklobutrazol biasanya menyebabkan dormansi tunas sehingga tunas yang telah terinduksi perlu diperlakukan dengan zat pemecah dormasi sebelum dapat terinisiasi. Berdasarkan hasil (Tabel 2) terlihat bahwa pada perlakuan paklobutrazol dosis 1,5 g/pohon (P1) hanya satu tanaman yang mengalami dormansi setelah terinduksi yaitu tanaman perlakuan P1K0 ulangan ke 3. Lima tanaman perlakuan P1 lain telah terinisiasi tanpa memerlukan aplikasi $\mathrm{KNO}_{3}$ sebagai zat pemecah dormansi.

Pada perlakuan paklobutrazol dosis 3 $\mathrm{g} /$ pohon (P2), dari lima tanaman yang terinduksi tiga diantaranya mengalami dormansi (P2K0 ulangan ke-2, P2K1 ulangan ke-2 dan ke-3) dan satu tanaman dapat terinisiasi tanpa aplikasi $\mathrm{KNO}_{3}$ (P2K0 ulangan ke-1). Diantara tiga tanaman yang mengalami dormansi, dua tanaman merupakan perlakuan K1. Aplikasi $\mathrm{KNO}_{3}$ terbukti dapat memecahkan dormansi tunas pada kedua tanaman tersebut. Keduanya mengalami inisiasi tujuh hari setelah aplikasi $\mathrm{KNO}_{3}$.

Berdasarkan hasil (Tabel 2) terlihat bahwa efek dormansi tunas semakin kuat pada dosis paklobutrazol yang lebih tinggi. Aplikasi paklobutrazol dengan dosis 1,5 g/pohon cenderung tidak menyebabkan dormansi tunas sedangkan aplikasi paklobutrazol dengan dosis 3 $\mathrm{g} /$ pohon cenderung menyebabkan dormansi tunas sehingga memerlukan aplikasi zat pemecah dormansi agar tunas yang telah terinduksi dapat terinisiasi untuk berbunga.

Dormansi tunas sebagai akibat aplikasi paklobutrazol terkait dengan ABA (Absisic Acid) yang merupakan hormon penyebab dormansi dan bersifat mencegah tunas yang dorman tumbuh kembali (Wang and Faust 1990). Purnomo dan Prahardini (1988) mengemukakan bahwa penghambatan biosintesis GA akan menyebabkan lintasan biosintesis beralih peran untuk melaksanakan biosintesis ABA. Hal ini disebabkan GA dan ABA disintesis dari prekursor yang sama yaitu asam mevalonat. GA dan ABA berbagi tahap awal biosintesis yang sama.

Pemecahan dormansi tunas oleh $\mathrm{KNO}_{3}$ terkait dengan etilen. Setelah diserap ke dalam jaringan, nitrat $\left(\mathrm{NO}_{3}^{-}\right)$akan direduksi menjadi nitrit $\left(\mathrm{NO}_{2}^{-}\right)$yang kemudian direduksi lebih lanjut membentuk ion amonium $\left(\mathrm{NH}_{4}{ }^{+}\right)$. Amonium akan menjadi sumber gugus amino ($\mathrm{NH}_{2}$ ) untuk menghasilkan asam amino. Salah satu asam amino tersebut adalah metionin, yaitu prekursor etilen yang dapat mendorong tunas untuk berdiferensiasi (Bondad, 1990). Selain itu unsur kalium dalam $\mathrm{KNO}_{3}$ yang berperan dalam mekanisme pembukaan stomata dan transpor asimilat dapat meningkatkan efisiensi fotosintesis sehingga energi yang terkumpul cukup banyak untuk memacu tunas yang dorman menjadi terdiferensiasi (Prawiranata $e t$ al., 1992).

Pada rambutan, tunas bunga telah memasuki tahap diferensiasi secara morfologi apabila malai bunga mulai terbentuk dan mulai terlihat pembentukan organ-organ bunga. Dari hasil Tabel 2, untuk perlakuan P0 satu tanaman yang terinisiasi berhasil memasuki fase diferensiasi, sedangkan untuk perlakuan P1 dan P2 semua tanaman yang terinisiasi memasuki fase differensiasi

\section{Jumlah Tunas Generatif}

Hasil analisis sidik ragam menunjukkan bahwa perlakuan paklobutrazol berpengaruh nyata terhadap rataan jumlah tunas generatif. Perlakuan paklobutrazol secara signifikan meningkatkan rataan jumlah tunas terinduksi, terinisiasi, dan terdiferensiasi.

Berdasarkan hasil ini terlihat bahwa perlakuan P1 memberikan hasil yang lebih baik dibandingkan perlakuan P2. Jumlah tunas terinduksi, terinisiasi, dan terdiferensiasi yang dihasilkan tanaman perlakuan P1 lebih banyak dibanding perlakuan $\mathrm{P} 2$.

Perlakuan $\mathrm{KNO}_{3}$ berdasarkan hasil analisis sidik ragam hanya berpengaruh nyata terhadap rataan jumlah tunas terinduksi. Unsur kalium dalam $\mathrm{KNO}_{3}$ dapat meningkatkan sintesis sukrosa, meningkatkan laju transportasi sukrosa dari mesofil daun dan meningkatkan pemuatan sukrosa pada floem (Marschner, 1986). Peranan kalium ini menyebabkan 
peningkatan translokasi sukrosa ke mata tunas yang kemudian akan menginduksi pembungaan.

Hasil pada penelitian ini sesuai dengan penelitian-penelitian sebelumnya yang membuktikan bahwa paklobutrazol dapat meningkatkan jumlah tunas bunga, diantaranya pada mangga (Purnomo dan Prahardini, 1998, Subhadrabandhu and Tongumpai, 1990, Kurian and Iyer, 1993), pir (Browning et al., 1992), dan jeruk sitrus (Okuda et al., 1996).

Browning et al., (1992) mengemukakan bahwa aplikasi $1000 \mathrm{mg} / \mathrm{l}$ paklobutrazol secara signifikan meningkatkan persen tunas yang berbunga pada pir yaitu 38\% berbanding $4 \%$ pada tanaman tanpa perlakuan paklobutrazol. Pada jeruk sitrus, aplikasi paklobutrazol dosis 1 g/pohon meningkatkan jumlah tunas bunga sebesar 60\% (Okuda et al., 1996). Sementara menurut Subhadrabandhu and Tongumpai (1990) aplikasi paklobutrazol dosis $1 \mathrm{~g} / \mathrm{m}^{2}$ tajuk mangga meningkatkan persentase tunas berbunga, yaitu $91,5 \%$ pada tanaman perlakuan paklobutrazol berbanding $15,7 \%$ pada tanaman tanpa perlakuan paklobutrazol.

Tabel 3. Rataan jumlah tunas generatif pada berbagai perlakuan paklobutrazol dan $\mathrm{KNO}_{3}$

\begin{tabular}{cccc}
\hline \hline \multirow{2}{*}{ Perlakuan Paklobutrazol } & \multicolumn{3}{c}{ Rataan Jumlah Tunas } \\
\cline { 2 - 4 } & Induksi & Inisiasi & Diferensiasi \\
\hline P0 & $2,333^{\mathrm{a}}$ & $0,666^{\mathrm{a}}$ & $0,333^{\mathrm{a}}$ \\
$\mathrm{P} 1$ & $14,667^{\mathrm{b}^{*}}$ & $8,667^{\mathrm{b}}$ & $5,667^{\mathrm{b}}$ \\
$\mathrm{P} 2$ & $10,833^{\mathrm{b}^{*}}$ & $7,500^{\mathrm{b}}$ & $5,750^{\mathrm{b}}$ \\
\hline \multirow{2}{*}{ Perlakuan $\mathrm{KNO}_{3}$} & & Rataan Jumlah Tunas \\
\cline { 2 - 4 } & Induksi & Inisiasi & Diferensiasi \\
\hline $\mathrm{K} 0$ & $7,222^{\mathrm{a}}$ & $3,750^{\mathrm{a}}$ & $2,750^{\mathrm{a}}$ \\
\hline \hline
\end{tabular}

Keterangan : Nilai yang diikuti huruf yang sama pada kolom yang sama tidak berbeda nyata berdasarkan DMRT pada taraf kepercayaan $95 \%$.

\section{Persentase Jumlah Tunas Terinisiasi, Terdiferensiasi, dan Gugur}

Berdasarkan hasil analisis sidik ragam, perlakuan paklobutrazol berpengaruh nyata terhadap persentase tunas terinisiasi yang terdiferensiasi namun tidak berpengaruh nyata terhadap persentase tunas terinduksi yang terinisiasi dan persentase tunas yang gugur hingga akhir pengamatan. Hasil analisis ragam juga menunjukkan bahwa perlakuan $\mathrm{KNO}_{3}$ tidak berpengaruh nyata terhadap ketiga peubah tersebut.

Tunas yang telah terinduksi tapi tidak berhasil terinisiasi atau telah terinisiasi tapi tidak berhasil terdiferensiasi dikarenakan tunas tersebut tetap dorman atau kembali ke fase vegetatif. Levy and Dean (1998) menyatakan bahwa pada beberapa spesies di bawah pengaruh kondisi lingkungan tertentu dapat terjadi pembalikan kondisi reproduktif, dimana setelah memasuki fase pembungaan terbentuk tunas vegetatif kembali. Proses pembalikan ini terjadi pada tanaman rambutan di bawah Biota Vol. X (2), Juni 2005 pengaruh curah hujan yang tinggi. Karena itu pada rambutan stimulus pembungaan dibutuhkan bukan hanya untuk menginduksi pembungaan tapi juga untuk mempertahankan perkembangan reproduktif.

Berdasarkan hasil (Tabel 4) persentase tunas terinisiasi pada perlakuan P1 dan P2 lebih besar dibandingkan pada perlakuan P0 meskipun tidak signifikan secara statistik. Persentase tunas terinisiasi pada perlakuan P2 juga lebih besar dibandingkan pada perlakuan P1 walaupun tidak berbeda nyata pada uji Duncan. Sedangkan untuk persentase tunas terdiferensiasi, perlakuan paklobutrazol (P1 dan P2) secara signifikan meningkatkan persentase tunas yang terdiferensiasi dibandingkan dengan perlakuan P0. Seperti halnya pada persentase tunas terinisiasi, persentase tunas yang terdiferensiasi pada perlakuan P2 lebih besar dibandingkan pada perlakuan P1. Hal ini mengindikasikan bahwa stimulus pembungaan pada tanaman yang diperlakukan dengan paklobutrazol lebih kuat 
dibandingkan pada tanaman tanpa perlakuan paklobutrazol, dan dengan semakin tinggi dosis aplikasi paklobutrazol kekuatan stimulus pembungaan semakin meningkat.

Tabel 4. Pengaruh paklobutrazol dan $\mathrm{KNO}_{3}$ terhadap persentase tunas terinisiasi, terdiferensiasi, dan gugur

\begin{tabular}{cccc}
\hline \hline \multirow{2}{*}{ Perlakuan Paklobutrazol } & \multicolumn{3}{c}{ Persentase Tunas (\%) } \\
\cline { 2 - 4 } & Terinisiasi & Terdiferensiasi & Gugur \\
\hline P0 & $23,75^{\mathrm{a}}$ & $33,85^{\mathrm{a}}$ & $100^{\mathrm{a}}$ \\
P1 & $50,09^{\mathrm{a}}$ & $74,80^{\mathrm{b}}$ & $66,79^{\mathrm{a}}$ \\
P2 & $61,61^{\mathrm{a}}$ & $76,56^{\mathrm{b}}$ & $82,69^{\mathrm{a}}$ \\
\hline \multirow{2}{*}{ Perlakuan $\mathrm{KNO}_{3}$} & \multicolumn{3}{c}{ Persentase Tunas (\%) } \\
& Terinisiasi & Terdiferensiasi & Gugur \\
\hline $\mathrm{K} 0$ & $36,70^{\mathrm{a}}$ & $75,00^{\mathrm{a}}$ & $84,37^{\mathrm{a}}$ \\
$\mathrm{K} 1$ & $53,19^{\mathrm{a}}$ & $63,90^{\mathrm{a}}$ & $76,73^{\mathrm{a}}$ \\
\hline \hline
\end{tabular}

Keterangan: Nilai yang diikuti huruf yang sama pada kolom yang sama tidak berbeda nyata berdasarkan DMRT pada taraf kepercayaan $95 \%$

Stimulus pembungaan pada tanaman tanpa perlakuan paklobutrazol (P0) dapat menginduksi pembungaan namun tidak cukup kuat untuk mempertahankan identitas dan determinasi meristem reproduktif. Hal ini terbukti dari nilai persentase terinisiasi dan terdiferensiasi yang rendah dan pada akhirnya $100 \%$ tunas yang telah terinduksi gugur. Sedangkan pada perlakuan P1 dan P2 stimulus pembungaan akibat perlakuan paklobutrazol cukup kuat untuk mempertahankan identitas dan determinasi meristem reproduktif walaupun kondisi lingkungan tidak mendukung. Besarnya persen keguguran tunas reproduktif diakibatkan faktor lingkungan berupa curah hujan yang tinggi.

\section{Pertumbuhan Panjang Malai}

Analisis sidik ragam tidak dapat diterapkan pada peubah panjang malai karena pada kombinasi perlakuan POK0 tidak ada tunas generatif yang terinisiasi sedangkan pada kombinasi perlakuan P0K1, P1K1, dan P2K0 malai bunga telah gugur sebelum terdiferensiasi sempurna. Menurut Backer and Van Der Brink (1965) panjang malai rambutan normalnya berkisar antara $10-25 \mathrm{~cm}$. Pada penelitian ini malai yang terdiferensiasi sempurna pada kombinasi perlakuan P1K0 dan
P2K1 masing-masing hanya mencapai panjang $40 \mathrm{~mm}$ dan $15 \mathrm{~mm}$. Hasil ini mengindikasikan bahwa aplikasi paklobutrazol memberikan efek pereduksian panjang malai. Terlihat bahwa semakin tinggi dosis paklobutrazol yang diaplikasikan panjang malai bunga semakin tereduksi.

Hasil ini sesuai dengan apa yang dikemukakan oleh Scarisbrick et al. (1985) bahwa panjang malai bunga tereduksi secara signifikan sebagai efek aplikasi paklobutrazol. Aplikasi paklobutrazol mereduksi panjang malai dikarenakan pemanjangan malai bunga merupakan proses yang distimulasi oleh GA. Maka perlakuan inhibitor biosintesis GA, seperti paklobutrazol, akan menghambat pemanjangan malai.

Menurut Purnomo dan Prahardini (1988) paklobutrazol menyebabkan bentuk malai bunga berubah dari bentuk kerucut panjang dan lancip menjadi bentuk kerucut pendek dan tumpul. Perubahan ini akan menyebabkan pembungaan yang semula terpusat di bagian tengah malai menjadi terletak di bagian pangkal malai. Hal ini akan mendukung peningkatan jumlah calon buah karena calon buah yang terletak pada pangkal malai berpeluang lebih besar untuk menjadi buah. 


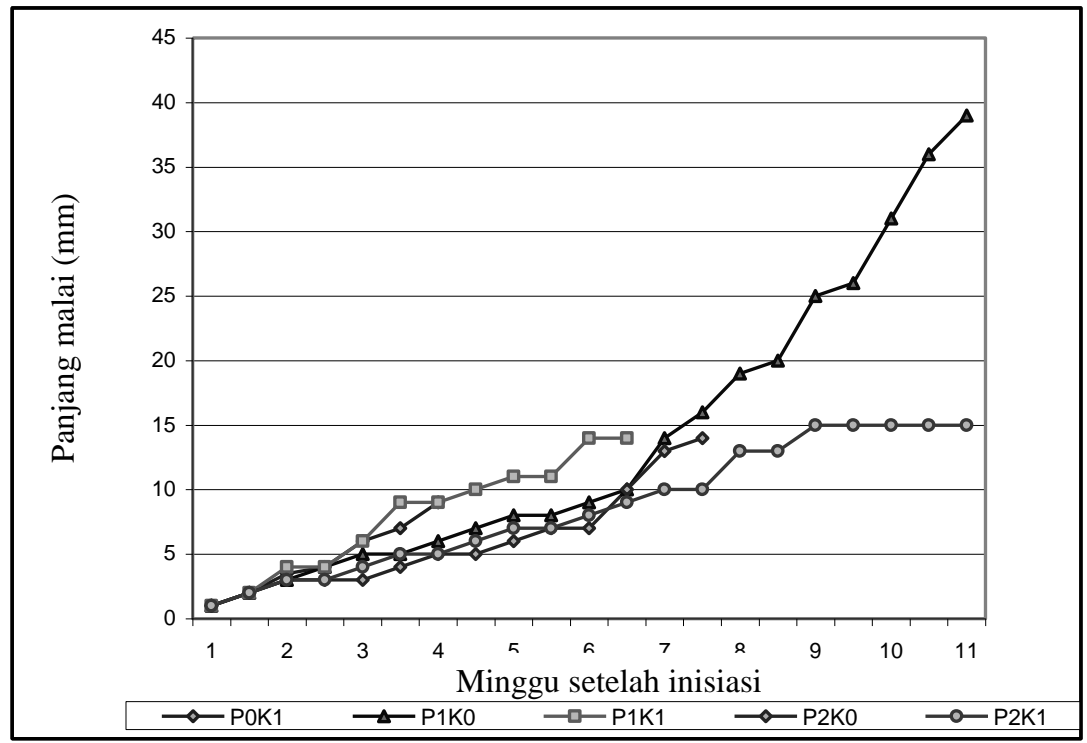

Gambar 2. Grafik pertumbuhan panjang malai.

\section{Kadar Klorofil Daun Pendukung Pembungaan}

Dari hasil (Tabel 5) terlihat bahwa perlakuan paklobutrazol meningkatkan kadar klorofil daun baik pada fase induksi, inisiasi, maupun diferensiasi. Hasil analisis ragam menunjukan bahwa perlakuan paklobutrazol signifikan meningkatkan kadar klorofil daun induksi dan inisiasi namun pengaruhnya tidak nyata terhadap kadar klorofil daun diferensiasi. Dosis paklobutrazol yang semakin tinggi semakin meningkatkan kadar klorofil daun.

Tabel 5. Pengaruh perlakuan paklobutrazol dan $\mathrm{KNO}_{3}$ terhadap kadar klorofil daun

\begin{tabular}{cccc}
\hline \hline Perlakuan Paklobutrazol & \multicolumn{3}{c}{ Kadar Klorofil Daun (mg/l) } \\
\cline { 2 - 4 } & Induksi & Inisiasi & Diferensiasi \\
\hline $\mathrm{P} 0$ & $0,9371^{\mathrm{a}}$ & $0,5669^{\mathrm{a}}$ & $0,7624^{\mathrm{a}}$ \\
$\mathrm{P} 1$ & $1,5349^{\mathrm{a}}$ & $1,1833^{\mathrm{ab}}$ & $1,3219^{\mathrm{a}}$ \\
$\mathrm{P} 2$ & $3,3334^{\mathrm{b}}$ & $1,8801^{\mathrm{b}}$ & $1,6580^{\mathrm{a}}$ \\
\hline Perlakuan $\mathrm{KNO}_{3}$ & Kadar Klorofil Daun $(\mathrm{mg} / \mathrm{l})$ \\
& Induksi & Inisiasi & Diferensiasi \\
\hline $\mathrm{K} 0$ & 2,3709 & $1,7465^{\mathrm{a}}$ & $0,9239^{\mathrm{a}}$ \\
$\mathrm{K} 1$ & 1,8180 & $1,1831^{\mathrm{a}}$ & $1,3967^{\mathrm{a}}$ \\
\hline \hline
\end{tabular}

$\overline{\text { Keterangan : Nilai yang diikuti huruf yang sama pada kolom yang sama tidak berbeda nyata berdasarkan DMRT pada taraf }}$ kepercayaan $95 \%$.

Pada fase induksi belum ada pengaruh $\mathrm{KNO}_{3}$

Peningkatan kadar klorofil akibat aplikasi paklobutrazol ini juga dilaporkan terjadi pada tomat, dan Brassica napus. Pada penelitian Berova and Zlatev (2000) aplikasi 1 $\mathrm{mg} / \mathrm{l}$ paklobutrazol pada tomat meningkatkan kadar klorofil total sebesar $15-16 \%$. Hasil yang serupa terjadi akibat aplikasi paklobutrazol pada $B$. napus yaitu daun menjadi lebih hijau gelap dan berukuran lebih kecil dibandingkan daun pada tanaman tanpa perlakuan paklobutrazol (Scarisbrick et al., 1985).

Menurut Peng et al. (1999) peningkatan kadar klorofil akibat aplikasi paklobutrazol juga berkorelasi dengan efek paklobutrazol terhadap penghambatan biosintesis GA. Diketahui bahwa peningkatan kadar GA menyebabkan daun berwarna lebih pucat (Peng et al., 1999). Wen and Chang (2002) mengemukakan bahwa hambatan dalam 
biosintesis GA ataupun dalam penanggapan GA menimbulkan fenotipe daun yang kecil/kompak dan berwarna hijau gelap. Fenotipe yang serupa ditampakkan oleh tanaman yang diperlakukan dengan inhibitor biosintesis GA seperti paklobutrazol. Analisis klorofil terhadap daun yang berwarna hijau gelap tersebut menunjukkan bahwa kandungan klorofilnya lebih tinggi sekitar 20-25\% dibandingkan daun tanaman kontrol.

Perbandingan kadar klorofil antara fase vegetatif dan fase pembungaan dan antar fase pembungaan disajikan pada Gambar 3. Dari grafik terlihat bahwa dari fase vegetatif ke fase induksi, yang merupakan fase awal pembungaan, kadar klorofil daun meningkat.
Tahap induksi merupakan transisi dari fase vegetatif menuju fase reproduktif. Levy and Dean (1998) serta King and Ben-Tal (2001) mengemukakan bahwa induksi pembungaan membutuhkan peningkatan suplai karbohidrat menuju apeks, karenanya pada tahap induksi pembungaan terjadi peningkatan laju fotosintesis. Peningkatan laju fotosintesis ini terkait erat dengan kadar klorofil, dimana peningkatan kadar klorofil total merupakan salah satu faktor utama yang menstimulasi peningkatan laju fotosintesis (Berova and Zlatev, 2000). Hal ini menjelaskan peningkatan kadar klorofil daun dari fase vegetatif ke fase induksi pembungaan.

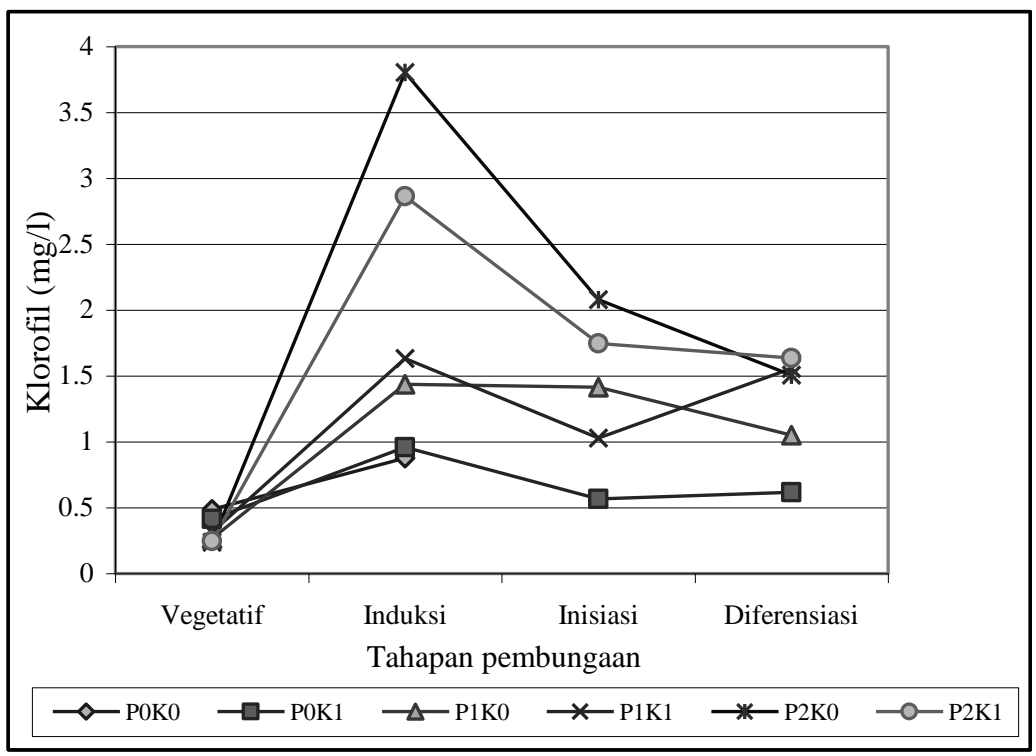

Gambar 3. Grafik pengaruh perlakuan dan fase perkembangan terhadap kadar klorofil daun.

Dari fase induksi ke fase inisiasi kadar klorofil daun pendukung pembungaan cenderung menurun. Fase inisiasi merupakan tahap awal pembentukan malai dan organ bunga. Fase ini membutuhkan banyak energi tetapi tidak sebesar pada fase induksi. Fase diferensiasi merupakan tahap perkembangan lebih lanjut malai dan organ bunga. Dari fase inisiasi ke fase diferensiasi kadar klorofil daun cenderung menurun tetapi tidak setajam penurunan kadar klorofil dari fase induksi ke fase inisiasi.
Dibandingkan dengan fase vegetatif, kadar klorofil daun pada fase pembungaan baik pada fase induksi, inisiasi, maupun diferensiasi lebih tinggi daripada kadar klorofil fase vegetatif. Dengan demikian fase pembungaan membutuhkan energi yang lebih banyak dibandingkan fase vegetatif.

\section{Kesimpulan}

Perlakuan paklobutrazol dapat menginduksi pembungaan tanaman rambutan 
di luar musim. Aplikasi paklobutrazol mempercepat terjadinya pembungaan, meningkatkan rataan jumlah tunas generatif, memperkuat stimulus pembungaan, menyebabkan tereduksinya panjang malai dan meningkatkan kadar klorofil daun.

Efek dormansi tunas semakin kuat pada dosis paklobutrazol yang lebih tinggi. Aplikasi paklobutrazol dosis 1,5 g/pohon cenderung tidak menyebabkan dormansi tunas sedangkan dosis $3 \mathrm{~g} /$ pohon cenderung menyebabkan dormansi tunas. Aplikasi $\mathrm{KNO}_{3}$ terbukti dapat memecahkan dormansi tunas akibat aplikasi paklobutrazol.

Pada penelitian ini dosis paklobutrazol yang optimum untuk menginduksi pembungaan rambutan adalah 1,5 g/pohon karena cenderung tidak menyebabkan dormansi tunas dengan rataan jumlah tunas generatif yang lebih tinggi dibandingkan dosis $3 \mathrm{~g}$ /pohon.

\section{Daftar Pustaka}

Arnon, D.I. 1949. Copper Enzym In Isolated Chloroplast, Polyphenoloxidase In Beta vulgaris. Plant Physiol. 24:1-15.

Backer, C.A. and Van der Brink, R.C.B. 1965. Flora of Java. Volume II. NVP Noordhoff-Groningen. Leyden.

Berova, M. and Zlatev, Z. 2000. Physiological Response and Yield of Paclobutrazol Treated Tomato Plants (Lycopersicon esculentum Mill.). Plant Growth Regulation 30:117-123.

Bondad, N.D. 1990. Off Season Mango Production In The Phillipines. FFTC. Taipei.

Browning, G., Kuden, A. and Blake, P. 1992. Site of (2RS,3RS)-Paclobutrazol Promotion of Axillary Flower Initiation in Pear cv. Doyenne du Comice. J. Hort. Sci 67:121-128.

Irdiastuti, R. 2002. Produksi dan Perubahan Fisiologi Rambutan Binjai Setelah Induksi Pembungaan Pada Masa Off-Year [tesis]. Institut Pertanian Bogor. Bogor.

King, R.W. and Ben-Tal, Y. 2001. A florigenic Effect of Sucrose in Fuchsia hybrida is Bocked by Gibberellin-Induced Assimilate Competition. Plant Physiol. 125:488-496.

Kurian, R.M. and Iyer, C.P.A. 1993. Chemical Regulation of Tree Size in Mango (Mangifera indica L.) cv. Alphonso. II. Effects of Growth Retardants on Flowering and Fruit Set. J. Hort. Sci. $68: 355-360$

Biota Vol. X (2), Juni 2005
Levy ,Y.Y. and Dean, C. 1998. The Transition to Flowering [Review]. Plant Cell 10:19731989.

Marschner, H. 1986. Mineral Nutrition of Higher Plants. Acad. Pr. London.

Mehouachi, Tadeo, J.F.R., Zaragoza, S., Primo-Millo, E., and Talon, M. 1996. Effects of Gibberellic Acid and Paclobutrazol on Growth and Carbohydrate Accumulation in Shoots and Roots of Citrus Rootstock Seedlings. J. Hort. Sci. 71:747-754.

Okuda, H., Kihara, T. and Iwagaki, I. 1996. Effects of Paclobutrazol Application to Soil at The Beginning of Maturation on Sprouting, Shoot Growth, Flowering and Carbohydrate Contents in Roots and Leaves of Satsuma Mandarin. $J$. Hort. Sci. 71:785-789.

Peng, J., Richards, D.E., Moritz, T., Cano-Delgado, A. and Harberd, N.P. 1999. Extragenic Suppressors of The Arabidopsis Gai Mutation Alter The Dose-Response Relationship of Diverse Gibberellin Responses. Plant Physiol. 119:1199-1207.

Prawiranata, W., Harran, S. and Tjondronegoro, P.D. 1992. Dasar-Dasar Fisiologi Tumbuhan Jilid II. Jurusan Biologi FMIPA Institut Pertanian Bogor. Bogor.

Purnomo, S. dan Prahardini, P.E.R. 1988. Perangsangan Pembungaan Dengan Paklobutrazol dan Pengaruhnya terhadap Hasil Buah Mangga (Mangifera indica L.). Penel. Hort. 27:16-24.

Rasiyanto, K. 2001. Pengaruh Pemberian Paklobutrazol dan Zat Pemecah Dormansi terhadap Pertumbuhan dan Pembungaan Tanaman Rambutan (Nephelium lappaceum Linn.) var. Binjai [Skripsi]. Institut Pertanian Bogor. Bogor.

Ryugo, K. 1988. Fruit Culture, Its Science and Art. John Wiley. New York.

Scarisbrick, D.H., Addo-Quaye, A.A., Daniels, R.W. and Mahamud, S. 1985. The Effect of Paclobutrazol on Plant Height and Seed Yield of Oil-Seed Rape (Brassica napus L.). J. Agric. Sci. 105:605-612.

Subhadrabandhu, S. and Tongumpai, P. 1990. Off-Season Production of Some Economic Fruit in Thailand. In: Proceedings of the International Seminar "Off-season Production of Horticultural Crops"; Taipei, 27 Nov-3 Dec 1989. Food and Fertilizer Technology Center. pp. 78-88. Taipei.

Thunyarpar. 1997. Physiological Aspect on Flowering of Lychee and Longan.Chiang May Univ. Chiang May. 
Tromp, J. 2000. Flower Bud Formation in Pome Fruits as Affected by Fruit Thinning. Plant Growth Regulation 31:27-34.

Wang, S.Y. and Faust, M. 1990. Metabolic Changes Associated With Flowering in Deciduous Fruit Trees. In: Proceedings of the International Seminar "Off-season Production of Horticultural Crops"; Taipei, 27 Nov-3 Dec 1989. Food and Fertilizer Technology Center. pp. 10-19. Taipei.

Wen, C.K. and Chang, C. 2002. Arabidopsis RGL1 Encodes a Negative Regulator of Gibberellin Responses. Plant Cell 14:87-100. 